\title{
“UNFATHOMABLE CALMNESS": BETRAYAL TRAUMA, SILENCE AND DISSOCIATION IN THE SECRET AGENT
}

\author{
Imen Chemengui \\ iD http:/orcid.org/0000-0003-2839-4788 \\ (University of Tunis, Tunisia)
}

\begin{abstract}
With the rise of trauma theory in late 19th century, researchers have focused on foregrounding the significance of some catastrophic events that pertain mainly to the collective, leaving other forms of trauma and their psychological aftermath on the individual underrepresented. In this paper, I focus on social traumas in Joseph Conrad's The Secret Agent, which seems to be overlooked by some critics whose insights highlight primarily its political aspect. The events of the novel revolve around the peculiar and traumatic experience of Winnie Verloc whose life is rife with betrayal and violence. Her recurrent exposure to successive shocking events culminates in her dissociation and, consequently, her suicide. To pin down what lies beneath Winnie's ambiguity, aloofness and silence in the novel, I mainly rely on trauma theory, drawing from studies on PTSD, betrayal and dissociation by several trauma scholars, such as, Cathy Caruth, Shoshana Felman, Jennifer Freyd, and others. Furthermore, this paper examines the inextricability of the past from the present in trauma through the breadth scrutiny of Winnie's psychological response to her excruciating experience. Hence the way the appalling past returns unbidden to shake Winnie's present.
\end{abstract}

Keywords: betrayal trauma, dissociation, violence, The Secret Agent, Conrad

The Secret Agent, which dwells on issues of anarchism and betrayal, is one of Conrad's most prominent political novels. In a letter to John Galsworthy, Conrad concedes that he did not intend the novel to be political and that his treatment of anarchism was beyond "its philosophical aspect." Nevertheless, critics who worked to unravel the novel's hidden mystery consider it a political novel par excellence and praise its complex plot and murky characters. Still, their construal revolves chiefly around the secret activities of a group of anarchists, paying scant attention to the pernicious effect of this political enterprise on characters' social lives. Furthermore, the silence or lack of speech of some characters renders the task of understanding their ambiguous personalities a daunting endeavour. Indeed, many critics think that the importance of The Secret Agent lies in its unprecedented depiction

${ }^{1}$ Joseph Conrad, The Collected Letters of Joseph Conrad, vol. 8, ed. Laurence Davies and Gene M. Moore (Cambridge: Cambridge University Press, 2007), p. 354. 
of "terrorism," which is a timely topic. Terry Eagleton postulates: "it includes the first suicide bombers in English literature, which makes it more relevant now than it was when it first appeared in 1907." ${ }^{2}$ However, this does not mitigate the importance of characters' social lives in the novel as well as the upheavals of individual experiences.

Conrad is aware of the importance of the social from the outset of the novel. The events revolve around a female protagonist, Winnie Verloc, whose childhood traumatic experiences of abuse and violence have culminated in her escape from her father's house, seeking refuge in an ostensibly secure yet loveless marriage. Conrad seems to sympathize with this female character through his astute depiction of the excruciating parental cruelty she and her brother have experienced:

She remembered brushing the boy's hair and tying his pinafores - herself in a pinafore still; the consolations administered to a small and badly scared creature by another creature nearly as small but not quite so badly scared; she had the vision of the blows intercepted (often with her own head), of a door held desperately shut against a man's rage (not for very long); of a poker flung once (not very far), which stilled this particular storm into the dumb and awful silence which follows a thunder-clap. And all these scenes of violence came and went accompanied by unrefined noise of deep vociferations proceeding from a man wounded in his paternal pride. ${ }^{3}$

Winnie Verloc exemplifies the life of an agonized English lady whose love for her mentally retarded brother and hopeless mother transcends her love for herself. "After the death of her father, Winnie found considerable consolation in the feeling that she need no longer tremble for poor Stevie. She could not bear to see the boy hurt. It maddened her" (TSA, p. 34). Winnie therefore has traded her happiness for the sake of her family's security. Although infatuated with the impecunious son of a butcher, she seems to forget about her emotions in favour of her family's happiness: "with peaceful pride she congratulated herself on a certain resolution she had taken a few years before. It had cost her some effort, and even a few tears" (TSA, p. 142). However, her husband seems to lead a different life from hers. Hiding behind the identity of a pornography shop owner, Mr Verloc serves as a secret agent for the Russian Embassy.

Winnie is held hostage in an insipid relationship which she pretends to enjoy till it is disrupted by her husband's dishonest motives and his betrayal of her brother's trust. The latter is presented in the novel as the scapegoat of Mr Verloc's perilous enterprise for anarchism in the country. Her brother is involved in a terrorist attack that culminates in his destruction. The realization that Verloc has led her brother to his demise instead of protecting him widens the rift with her husband and drives her mad. Consequently, and in an unexpected backlash, she murders him. The incident constitutes the turning point in the novel since it brings Winnie's frustratingly intricate personality to its extreme. Seeking escape abroad, she elopes with Verloc's associate who fakes his love for her by veiling his selfish motives. This last traumatiz-

\footnotetext{
${ }^{2}$ Terry Eagleton qtd in Norman Sherry, "The Greenwich Bomb Outrage and The Secret Agent." The Review of English Studies 18, no. 72 (1967), p. 46.

${ }^{3}$ Joseph Conrad, The Secret Agent (Cambridge: Cambridge University Press, 1984), p. 183. Subsequent references to The Secret Agent will be marked in the text by the letters TSA in parentheses with the corresponding page number from the cited edition.
} 
ing deception makes her lose trust in peoples' ostensibly good intentions and thus leads to her fragmentation: "Her personality seemed to have been torn into two pieces, whose mental operations did not adjust themselves very well to each other" (TSA, p. 192). Such fragmentation winds up with her fatal enactment: committing suicide through drowning.

\section{WINNIE'S EMOTIONAL BOND WITH HER BROTHER}

Winnie's love for her brother is peculiar in the novel. Her care for Stevie transcends that of a normal sister; it is simply maternal-like affection. Her passion goes back to her childhood days when Conrad lays emphasis on her "maternal vigilance" concerning Stevie. He claims that Winnie "found an object of quasi-maternal affection in her brother," whereupon she has abstained from having children and sought the paternal affection in the figure of Verloc:

After the death of her father, she found considerable consolation in the feeling that she needs no longer tremble for poor Stevie. She could not bear to see the boy hurt. It maddened her. As a little girl she had often faced with blazing eyes the irascible licensed victualler in defense of her brother. Nothing now in Mrs Verloc's appearance could lead one to suppose that she was capable of a passionate demonstration. (TSA, p. 34)

Winnie has kept her affection repressed just like her repugnance for her husband. Ellen Burton Harrington has attributed her vengeful crime of stabbing Mr Verloc to the fires of indignation stemming from her "maternal passion" for Stevie and her sense of marital betrayal. Harrington examines Winnie's complex personality in light of Cesar Lomboroso's theory of atavism which shows how maternal passion or marital love twists into criminal motivation. ${ }^{4}$ She further argues: "A woman regards her child as a part of herself, providing for him and resenting in her own person the injuries inflicted on him, especially while he is little and cannot provide for himself." It is Stevie's utter dependence on his sister's care and protection that leads to her exasperation and madness upon losing him.

Mrs Verloc is represented as a taciturn character whose love for Stevie is never expressed in words. Her maternal care and "meretricious splendour" render the meaning of her life inextricable from her brother's happiness. Her thoughts are always veered towards her brother's "difficult existence from his earliest days" (TSA, p. 108). Winnie's single objective in life is to prove her magnanimous affection for the poor boy. "She saw herself putting the boy to bed by the light of a single candle on the deserted top floor of a 'business house,' dark under the roof and scintillating exceedingly with lights and cut glass at the level of the street like a fairy palace" (TSA,

\footnotetext{
${ }^{4}$ Ellen Burton Harrington, "The Female Offender, the New Woman, and Winnie Verloc in The Secret Agent," The Conradian 32, no. 1 (2007), pp. 57-58.

${ }^{5}$ Harrington, "Female Offender," p. 60.
} 
p. 108). Her shock when facing Stevie's death and her husband's betrayal hinders her capacity to cope with such experiences:

Mrs Verloc's mental condition had the merit of simplicity; but it was not sound. It was governed too much by a fixed idea. Every nook and cranny of her brain was filled with the thought that this man, with whom she had lived without distaste for seven years, had taken the "poor boy" away from her in order to kill him- the man to whom she had grown accustomed in body and mind; the man whom she has trusted, took the boy away to kill him! In its form, in its substance, in its effect, which was universal, altering even the aspect of inanimate things, it was a thought to sit still and marvel at forever and ever. (TSA, p. 143)

Her brother's horrific and sudden death along with her childhood verbal and physical abuse culminate in her suicide. The Secret Agent, Ellen Burton Harrington notes, illuminates human character through its thorough yet simple analysis of Mrs Verloc's personality. ${ }^{6}$ The narrative of the novel, Harrington argues, is "more heightened, more selective, and more sensational than most personal narratives that emerge in clinical work." It probes into Winnie's complex character. She is, at some times, caring and quiet, and at others sternly protective and murderous.

From the outset of the novel Stevie's delicate and easy-to-manipulate character is brought to the fore. It constitutes an encumbrance for both Winnie and her mother whose lives' meaning and worth become premised on the protection of poor Stevie. Such a view is substantiated by Winnie's incessant maternal vigilance that fastens upon every nook and cranny of her brain. However, although she might seem inordinately caring, Winnie cannot prevent her brother's clumsy behaviour from plunging him into all sorts of trouble. At the age of fourteen, he is tricked by two boys to set off fireworks in the stairwell of an office-building, which ends in a huge commotion. "The two office boys had worked upon his feelings by tales of injustice and oppression till they had wrought his compassion to the pitch of that frenzy" (TSA, p. 4). Through this scene, Conrad makes no bones about foregrounding Stevie's naive and vulnerable character, foreshadowing his disintegration and moral collapse.

The novel's flow of events and its structure are linked to the character of Stevie whose relationship with Winnie constitutes the focal point of my construal. What strikes a chord with readers about Stevie's excruciatingly contemptible death is not the event per se, but rather Winnie's maniacal reaction to the loss of her brother, which the narrator ascribes to her quasi-maternal affection. Describing Stevie's heartrending death, Conrad astutely debunks its effects on the unfortunate man's sister: "As if the homeless soul of Stevie had flown for shelter straight to the breast of his sister, guardian, and protector, the resemblance of her face with that of her brother grew at every step, even to the droop of the lower lip, even to the slight divergence of the eyes" (TSA, p. 116). Despite its painful impact, Stevie's death is what sets his sister free at the end of the novel as she utterly manages to get rid of what used to stall her happiness.

\footnotetext{
${ }^{6}$ Harrington, "Female Offender," p. 66.

${ }^{7}$ Harrington, "Female Offender," p. 66.
} 
Although overwhelmed by rage and dismay, Mrs Verloc pulls herself together and with the splendour of a free yet vengeful wife, she murders Verloc. The description of Winnie deliberating on her husband's assassination is significant in the novel since it reveals her extreme contempt and resentment toward the man she has entrusted her life to. She wears all black, preparing to mourn her husband who is yet to die.

\section{THE BODY'S REACTION TO TRAUMA: DISSOCIATION AS A DEFENCE MECHANISM}

The American Psychiatric Association defines dissociation as "a disruption in the usually integrated function of consciousness, memory, identity or perception of the environment." "According to Jennifer Freyd:

Dissociation functions as the last resort when escape is not a viable option. In cases of betrayal trauma, it would be adaptive to learn to compartmentalize (i.e. dissociate) traumatic experiences from conscious awareness. Allowing them into consciousness would result in even more severe consequences, jeopardizing the person's well-being. ${ }^{9}$

Cathy Caruth also argues that memory disintegration or dissociation is an important part of post traumatic stress disorder (PTSD). The aftermath of the recursive exposure to traumatic experiences engenders the cognitive loss of information process since the consciousness tends to deliberately repress or erase such experiences. However, parts of the events that are engraved in the unconscious impulsively return through repetitive distorted memories to haunt the survivor:

Pathologies of memory are characteristic features of post-traumatic stress disorder (PTSD). These range from amnesia for part, or all, of the traumatic events to frank dissociation, in which large realms of experience or aspects of one's identity are disowned. Such failures of recall can paradoxically coexist with the opposite: intruding memories and unbidden repetitive images of traumatic events. ${ }^{10}$

Therefore, dissociation becomes the body's defence mechanism against the remembrance of a horrific past, which is thereby reflected in the victim's sense of detachment and lack of communication with the outside world.

Mrs Verloc is depicted as a silent character who lacks the common forms of speech to communicate or express herself. Her voice is scarcely heard in the novel,

${ }^{8}$ Timo Giesbrech, et al. "Cognitive Processes in Dissociation: An Analysis of Core Theoretical Assumptions," Psychological Bulletin 134, no. 5 (2008), p. 617.

${ }^{9}$ Timo Giesbrecht and Harald Merckelbach, "Betrayal Trauma Theory of Dissociative Experiences: Stroop and Directed Forgetting Findings," The American Journal of Psychology 122, no. 3 (Fall 2009), pp. 337-338.

${ }^{10}$ Mark S. Greenberg and Bessel A. van der Kolk, "Retrieval and Integration of Traumatic Memories with the 'Painting Cure,"' in Psychological Trauma, ed. Bessel A. van der Kolk (Washington: American Psychiatric Publishing, 1987), p. 191. Quoted in Cathy Caruth, ed., Trauma: Explorations in Memory (Baltimore, MD: JHU Press, 1995), pp. 152-153. 
which is notably the effect of her childhood abuse that returns through symptoms of secrecy and repression. Winnie does not seem to overcome or recover from her childhood trauma; her taciturnity bears the scars of such an unhealed wound. The secret of her traumatic experience as a child is never revealed openly; because she is a "woman of singularly few words, either for public or private use" (TSA, p. 108). Had she recognized such an experience in her consciousness, Winnie would probably have been more verbal and open to speak her agonies. Instead, she seems to "dissociate" and repress her past in an attempt to avoid re-traumatization.

Judith Lewis Herman explains that trauma victims' lack of speech is primarily due to their resistance to accepting and integrating what has happened to them. ${ }^{11}$ Likewise, Jennifer Joy Freyd argues that "psychogenic amnesia" is a natural defence to not only alleviate or even block pain, ${ }^{12}$ but also to maintain the relationship with the caregiver. It is worth noting however, that Winnie seems to be mindful enough to recognize her father's abuse because she has never longed to retain her filial bond with him. She has rather escaped his violence by seeking refuge in a barren marriage. Nevertheless, as repeatedly averred by Conrad, her phobic feelings of replicating childhood suffering affect her marriage, as is revealed through her rigid and apathetic attitude towards her husband. Conrad describes her relationship with the latter as sexually desolate, insipid and unfulfilling:

She moved not, massive and shapeless like a recumbent statue in the rough; he remembered her wide-open eyes looking into the empty room. She was mysterious, with the mysteriousness of living beings. And he was also indolent, with the indolence which is so often the secret of good nature. He forbore touching that mystery out of love, timidity, and indolence. There would be always time enough. For several minutes he bore his suffering silently in the drowsy silence of the room. (TSA, p. 79)

Even when Mr Verloc tries to arouse the feminine side in her, so to speak, by initiating a general conversation which he believes will pave the way for an intimate one, Winnie seems to be motionless and uncaring. She even keeps her eyes wide open and lies very still while hearing that her husband will be on leave for a fortnight (TSA, p. 79);

${ }^{11}$ In her book Trauma and Recovery, Herman argues that "the psychological distress symptoms of traumatized people simultaneously call attention to the existence of an unspeakable secret and deflect attention from it. This is most apparent in the way traumatized people alternate between feeling numb and reliving the event. The dialectic of trauma gives rise to complicated, sometimes uncanny alterations of consciousness, which George Orwell, one of the committed truth-tellers of our century, called 'doublethink,' and which mental health professionals, searching for a calm, precise language, call 'dissociation.' It results in the protean, dramatic, and often bizarre symptoms of hysteria which Freud recognized a century ago as disguised communications about sexual abuse in childhood." Judith L. Herman, Trauma and Recovery: The Aftermath of Violence - From Domestic Abuse to Political Terror (New York: Basic Books, 2015), p. 1.

${ }^{12}$ In her article, "Betrayal Trauma: Traumatic Amnesia as an Adaptive Response to Childhood Abuse," Ethics \& Behavior 4, no. 4 (1994), pp. 307-329, Freyd claims that "betrayal trauma suggests that psychogenic amnesia is an adaptive response to childhood abuse. When a parent or other powerful figure violates a fundamental ethics of human relationship, victims may need to remain unaware of the trauma not to reduce suffering but rather to promote survival. Amnesia enables the child to maintain an attachment with a figure vital to survival, development, and thriving." (p. 307). 
and impassive, like an automaton, she puts the light out and makes no bones about telling him that she will be fine taking care of poor Stevie.

In her seminal article " 'Sudden Holes in Space and Time': Trauma, Dissociation, and the Precariousness of Everyday Life," Carola M. Kaplan points out that "one characteristic of pathological dissociation is emotional constriction and vulnerability to retraumatization and fragmentation." ${ }^{.3}$ Dissociation becomes the mind's defence mechanism against the inadvertent repetition or return of the traumatic experience. It is "enlisted by the mind to proactively assure that the destabilizing shock of the trauma is never repeated." ${ }^{14}$ It is worth mentioning however, that it is not clearly stated in the text whether Winnie dissociates or represses her trauma. In Trauma: Explorations in Memory, Bessel A. van der Kolk and Onno van der Hart, reflecting on Freud's analysis of repression, claim that trauma cannot be both repressed and dissociated at once since there is a difference between the two. According to the scholars, the former "reflects a vertically layered model of mind," 15 where the subject tries to repress traumatic memories downward, towards the unconscious, and thus no possible access to them is retained; "Only symbolic, indirect indications would point to their assumed existence." 16 On the other hand, dissociation reflects "a horizontally layered model of mind" where the subject tries to forget an already existing memory in an "alternate stream of consciousness." 17 Such dissociations happen during both the traumatic event and its reenactment.

According to Freyd, dissociation invokes "an immediate blanking out of reality such that memories are not stored in the first place." 18 Indeed, dissociation does not only imply the absence of memories or thoughts, but it also reflects on the blanking out of feelings and sense of connectedness, which is very obvious in Winnie's sense of aloofness. Her detachment and "unfathomable calmness" are indeed symptoms of her dissociation. To dissociate, Lenore Terr argues "is to partly turn off the psychological apparatus that fully perceives, registers, and stores memories," 19 which is again revealed through Winnie's indifference towards knowledge. She is even at times reluctant to perceive reality and get full access of it. Winnie's strength lies in her ability to always keep a stiff upper lip on anything she perceives, as she averts her eyes from what happens around her. Winnie tries to find resort in dissociation.

${ }^{13}$ Carola M. Kaplan, “'Sudden Holes in Space and Time': Trauma, Dissociation, and the Precariousness of Everyday Life," Psychoanalysis Inquiry 33, no. 5 (2013), p. 469.

${ }^{14}$ Philip M. Bromberg qtd in Kaplan, p. 472.

${ }^{15}$ Bessel A. van der Kolk and Onno van der Hart, "The Intrusive Past: The Flexibility of Memory and the Engraving of Trauma," in Trauma: Explorations in Memory, ed. Cathy Caruth (Baltimore: Johns Hopkins University Press, 1995), p. 168.

${ }^{16}$ Van der Kolk, van der Hart, "The Intrusive Past," p. 168.

${ }^{17}$ Van der Kolk, van der Hart, "The Intrusive Past," p. 168.

${ }^{18}$ Jennifer J. Freyd, Betrayal Trauma: The Logic of Forgetting Childhood Abuse (Cambridge, MA: Harvard University Press, 1996), p. 19.

${ }^{19}$ Lenore C. Terr, "Childhood Traumas," Psychotraumatology (1995), p. 85. 


\section{SILENCE OF/IN TRAUMA}

Winnie's childhood experiences along with the burden of looking after her retarded brother have brought her apathy to its extreme. She is a person with the instinctive conviction that "things do not bear looking into very much" (TSA, p. 79), something that Conrad emphasizes repeatedly in the novel. Such a view is substantiated not only through her relationship with her husband, but also with others. Winnie seems to live in a world she hatches for herself, totally detached from what is happening around her, living in a "tremendous state of solitariness" (TSA, p. 189). Her aloofness is amalgamated with her "unfathomable reserve," especially with the male customers and anarchists who drop by her husband's parlour. In the novel, Conrad notes that Winnie maintains a "veiled face" while connecting with others, even her husband.

Winnie's detachment, however, is also deemed part of her fascinating personality, as Conrad concedes in the novel, since many characters, like Mr Verloc and Stevie, seem susceptible to her silence and sustained "unfathomable indifference" (TSA, p. 3). Winnie's lack of speech is indeed inextricable from her agonizing experiences of violence, loss and abuse. Her opacity and silence are at the heart of historical catastrophe since words and language fall apart when seeking to represent trauma. Silence, Lea Wernick Fridman argues, bears the marks of a historical trauma that resists representation. ${ }^{20}$ Such a view has its bearings on Caruth's argument in which she notes that silence confides "the story of a wound that cries out, that addresses us in the attempt to tell us of a reality or truth that is not otherwise available. This truth, in its delayed appearance and its belated address, cannot be linked only to what is known, but also to what remains unknown in our very actions and our language." 21 Silence therefore becomes a way to recognize horror.

Winnie's speechlessness is born out of years of domestic abuse and violence. No words can so faithfully reveal her excruciatingly painful experience and maintain its speakability. The absence of language throughout Winnie's life corroborates the presumption that something harrowing is being eclipsed. Her taciturnity and stilted speech express her integration of a trauma that begs to be told or debunked; yet it lies beyond the realm of speech. Dwelling on the significance of silence in revealing suffering, Shira Wolosky claims in her book Language and Mysticism: The Negative Way of Language in Eliot, Beckett, and Celan that:

${ }^{20}$ This is referred to in her seminal book, Words and Witness: Narrative and Aesthetic Strategies in the Representation of the Holocaust. She avers in her analysis of features of silence in Heart of Darkness that "the foregrounded silence in the novel, whether tonal or structural, involves a very specific kind of unrepresentability, one that is linked to traumatic historical experience. It consists of that within catastrophic experience that exceeds and lies outside words - a silence so dense with historical process, death, contingency, and chaos, that the mere glimpse of it (Kurtz's famous whisper of horror, for example) threatens to eclipse the order inevitably implied by the literal narrative of Marlow's journey to find Kurtz." Lea Wernick Fridman, Words and Witness: Narrative and Aesthetic Strategies in the Representation of the Holocaust (New York: SUNY Press, 2012), pp. 34-35.

${ }^{21}$ Cathy Caruth, Unclaimed Experience: Trauma, Narrative, and History (Baltimore, MD: Johns Hopkins University Press, 2016), p. 4, emphasis added. 
Language is made dumb in face of a meaning ultimately inaccessible, an event too terrible to declare or formulate, a despair of any significant order. Silence will not, that is, paradoxically assert penetration into a divine or ideal realm beyond utterance - it will instead make the final unavailability of any reference point for orienting language and experience. ${ }^{22}$

Winnie's linguistic refusal and propensity towards seclusion evoke her distrust in human beings' real motives. Unlike other characters in Conrad's novels, her early deceptions with her father seem to make her immune to all sorts of illusions. She seems to live in her own world, bearing the arduous task of looking after a handicapped child and dauntingly endeavouring to endure a tasteless relationship. Thus, she does not see in her husband the illusion of the faithful and caring lover. However, she trusts him for her brother's life and well-being. She creates the illusion that $\mathrm{Mr}$ Verloc can be the figure of a father and caregiver, only for her ideals to be shattered by the iniquitous scheme that brings about Stevie's destruction.

\section{"VICARIOUS TRAUMA": WITNESSING AND LISTENING TO DEATH}

Mrs Verloc seems to be caught in Herman's dialectic of trauma, not only as a direct victim, but also as a witness. ${ }^{23}$ She wavers between the "minimization" and "numbing" of her past traumas. Her silence is a consequence of not only her direct exposure to violence, but also of her act of witnessing and listening to her brother's traumatic experiences. In her seminal book, Trauma and Recovery, Herman refers to the idea of "vicarious traumatization," 24 stressing how trauma can become contagious through listening and witnessing. She dwells on cases where some therapists generated PTSD due to their incessant listening to victims' stories of violence and abuse. Winnie seems to be overwhelmed by the images and sounds of her brother's howls upon putting hot iron on his skin - an image that returns to repeatedly intrude into her dreams. Unlike Herman, Caruth relates the "dialectic of trauma" to the notion of time. In her

${ }^{22}$ Shira Wolosky, Language Mysticism: The Negative way of Language in Eliot, Beckett, and Celan (Stanford: Stanford University Press, 1995), p. 234.

${ }^{23}$ In her study of the effects of witnessing and listening to trauma by therapists, Herman avers, "The dialectic of trauma constantly challenges the therapist's emotional balance. The therapist, like the patient, may defend against overwhelming feelings by withdrawal or by impulsive, intrusive action. The most common forms of action are rescue attempts, boundary violations, or attempts to control the patient. The most common constrictive responses are doubting or denial of the patient's reality, dissociation or numbing, minimization or avoidance of the traumatic material, professional distancing, or frank abandonment of the patient. Some degree of intrusion or numbing is probably inevitable. The therapist should expect to lose her balance from time to time with such patients." (Herman, Trauma and Recovery, p. 107).

24 "Trauma is contagious. In the role of witness to disaster or atrocity, the therapist at times is emotionally overwhelmed. She experiences, to a lesser degree, the same terror, rage, and despair as the patient. This phenomenon is known as "traumatic counter transference" or "vicarious traumatization." The therapist may begin to experience symptoms of posttraumatic stress disorder. Hearing the patient's trauma story is bound to revive any personal traumatic experiences that the therapist may have suffered in the past. She may also notice imagery associated with the patient's story intruding into her own waking fantasies or dreams." (Herman, Trauma and Recovery, p. 90). 
views, victims are caught in the dialectic of past and present traumas or, in other words, within the dialectic of forgetting past traumas and reliving them in the present.

Winnie's "impenetrable calmness" (TSA, p. 143) and stillness seem to be endemic all the way through her cohabitation with her husband whose infatuation and devotion, are at some times kept at bay and gently revealed at others. It is crucial to note that Winnie's lack of speech is due not only to her childhood traumatic memories, but also to the emotionally barren life befalling her marriage. The latter is what causes her re-traumatization and reluctance or inability to look deeply into things. Kaplan concedes the dangerous aspect of her lack of curiosity, which is also mentioned in the novel: "Mrs Verloc wasted no portion of this transient life in seeking for fundamental information. This is a sort of economy having all the appearances and some of the advantages of prudence" (TSA, p. 130). According to Kaplan, her unwillingness to seek information on what he calls "dissociative blindness," although it "keeps at bay her distaste at living with the physically repellent Verloc, also keeps her from understanding the motives of people she depends on and from recognizing actual danger when it threatens. ${ }^{.25}$

Winnie does not want to penetrate the surface of things lest she perceive the ugliness of life again; however, her prudence does not prevent her from facing the horror of her brother's gruesome death, which returns to haunt her ostensibly unruffled present:

Trembling all over with irrepressible shudders, she saw before her the very implement with its ghastly load scraped up from the ground. Mrs Verloc closed her eyes desperately, throwing upon that vision the night of her eyelids, where after a rain like fall of mangled limbs the decapitated head of Stevie lingered suspended alone, and fading out slowly like the last star of a pyrotechnic display. (TSA, p. 116)

The fact that her indifference prevents her from discerning her husband's vile motives overwhelms Winnie with a sense of guilt and enmeshes her further in a state of fragmentation and disunity: "her personality seemed to have been torn into two pieces, whose mental operations did not adjust themselves very well to each other" (TSA, p. 113).

In the scene of imagining her brother's severed head, Winnie cannot avoid the pictorial return of the Greenwich Park explosion memories and the image of her brother's disintegration and demise. The striking image of Stevie's remains "resembles a cannibal feast, and the apocalyptic image of his decapitated head amongst a rain-like fall of mangled limbs signifies dispersal" (TSA, p. 196). Indeed, the most shocking image in the novel is that of Stevie's remains:

A heap of rags, scorched and bloodstained, half concealing what might have been an accumulation of raw material for a cannibal feast. And meantime the Chief inspector went on peering at the table with a calm face and the slightly anxious attention of an indigent customer bending over what may be called the by-products of a butcher's shop with a view to an inexpensive Sunday dinner. (TSA, pp. 70-71)

${ }^{25}$ Kaplan, "Sudden Holes," p. 9. 
These are the images that return to overwhelm and haunt Winnie. It is only through dissociation that she relentlessly tries to overcome what happened, as she averts her eyes from those images to resist witnessing.

\section{"EMPIRICAL TRUTHS": THE IMPORTANCE OF VISION AND THE EYE}

In the novel, speech seems to be substituted by body language. Conrad never ceases to refer to Winnie's physical features and to emphasize their importance for understanding and communicating her trauma. In Empirical Truths and Critical Fictions: Locke, Wordsworth, Kant, Freud, Caruth delineates the importance of physical experiences to obtain knowledge. She dwells on John Locke's concept of empiricism, according to which "understanding becomes comprehensible to itself in an experience very much like that of visual perception." ${ }^{" 26}$ The inextricability of comprehension from visual perception is revealed thoroughly in The Secret Agent through Conrad's multifarious references to Winnie Verloc's eyes. The latter show her transformation from a quiescent to a fully cognizant person. Her eyes, as described by Conrad, reflect her character transition par excellence. The importance of the pictorial or spectacular is omnipresent in the novel and reveals the importance of the image in relation to trauma.

At the outset, the description of her eyes seems to align with her philosophy of indifference, covered with a hat, "immovable" (TSA, p. 117), "turned to the roof of the cab" (118), or "staring straight before her" (127), or "looking fixedly at a blank wall" (109). Her dormant eyes prevent her from penetrating beneath the surface of things, and thus she fails to recognize important things such as her husband's real motives. Strikingly, Winnie's understanding comes with the changes in her eyes which Conrad frequently refers to so as to prepare for her character transition. This again evokes John Locke's concept of empiricism, where he "establishes physical perception as a model for the way in which understanding comes to know itself." 27 Winnie's understanding of the world around her becomes tantamount with her physical perception of things. In chapter eight of the novel her dormant eyes show "a subtle change" upon recognizing the great impact of her mother's absence on the family, which foretells the coming changes in her character in the novel after witnessing her brother's death.

In chapter nine, Conrad shows the irrevocable change in Winnie's eyes which seem to "grow bigger," then open so wide that they look like "two black holes" and,

${ }^{26}$ This passage suggests that "understanding is completely available to itself because its ideas come from places within its experience: from the external world perceived in visual observation (or by means of 'sensation') and the internal world perceived in mental observation (or by means of 'reflection')." For ideas to come "from experience" means that they can be "observed," either through the eye or through its analogue, the understanding." Cathy Caruth, Empirical Truths and Critical Fictions: Locke, Wordsworth, Kant, Freud (Baltimore, MD: Johns Hopkins University Press, 2009), p. 7.

${ }^{27}$ John Locke qtd in Caruth, Empirical Truths. Locke reveals the dependence of certain ideas on sensation (Caruth, Empirical Truths, p. 12). 
in contrast to what was before, appear to notice every minor change around her, and to penetrate the horror of death: "Mrs Verloc who always refrained from looking deep into things was compelled to look into the very bottom of this thing" (TSA, p. 153). She becomes scrupulously aware of the minor details which she used to overlook at the beginning of the novel. The descriptions of Winnie's eyes delineate her transition from a still, indifferent and superficial character to a more thoughtful one. In the scene preceding her husband's murder, Winnie's looks at him become lethal stares Mr Verloc cannot figure out the creeping danger they carry. "It was not a wild stare, and it was not inattentive, but its attention was peculiar and not satisfactory, inasmuch that it seemed concentrated upon some point beyond Mr Verloc's person. The impression was so strong that Mr Verloc glanced over his shoulders" (TSA, p. 177). Through this description, Winnie seems to gain some extraordinary power, and her shallowness has transformed into an "unfathomable depth" that does away with her past ignorance and indifference. However, her depth comes with her retraumatization, facing the horror of death.

Nevertheless, Stevie's death, although excruciatingly painful for her, allows her to live down her feeling of remorse since she seems to pass the buck to Mr Verloc. Her old feelings of resentment for her father, therefore, veer towards her husband who in her views allows himself to die easily: "The stabbing of Mr Verloc had been only a blow. It had relieved the pent-up agony of shrieks strangled in her throat, of tears dried up in her hot eyes, of the maddening and indignant rage at the atrocious part played by that man, who was less than nothing now, in robbing her of the boy" (TSA, p. 118). In the scene of Mr Verloc's death, Conrad lays emphasis on the changes in her eyes and her vengeful stares at his dead body. He astutely describes Mr Verloc's stillness, "his habitual ease," and comfort (TSA, p. 216), which awakens Winnie from her state of indifference and blindness to a state of complete understanding and depth. Winnie's eyes "grow still larger," close and then open (TSA, p. 215), which reveals her shock upon witnessing her atrocious perpetration. Unlike the other chapters, the description of her eyes towards her husband's death comes to its extreme:

Her fine, sleepy eyes, travelling downward on the track of the sound, became contemplative on meeting a flat object of bone which protruded a little beyond the edge of the sofa. It was the handle of the domestic carving knife with nothing strange about it but its position at right angles to Mr Verloc's waistcoat and the fact that something dripped from it. (TSA, p. 216)

Also the description bears Winnie's traumatic assimilation of her husband's death through listening. The haunting sound of the trickling blood returns to fasten upon her mind, and makes her discern in depth the ugliness of her dehumanization:

Dark drops fell on the floor cloth one after another, with a sound of ticking growing fast and furious like the pulse of an insane clock. At its highest speed this ticking changed into a continuous sound of trickling. Mrs Verloc watched that transformation with shadows of anxiety coming and going on her face. It was a trickle dark, swift, thin. . . Blood! At this unforeseen circumstance Mrs Verloc abandoned her pose of idleness and irresponsibility. With a sudden snatch at her skirts and a faint shriek she ran to the door, as if the trickle had been the first sign of a destroying flood. (TSA, p. 116) 
Driven by her quasi-maternal affection for her brother, Winnie's vengeful motives undermine the human side in her and thus lead to her mad backlash. What strikes the reader in this scene is Conrad's description of Winnie as a free woman. Her freedom infers her detachment from both her previous life with her husband and her impeding simplicity and shallowness. Winnie finds herself trapped in an incomprehensible world of shocking images which she cannot assimilate, yet they return to haunt her. In his description of this process of trauma return, Greg Forter holds: "a punctual incursion on the mind, having dissociated consciousness from itself, installs an unprocessed memory-trace that returns unbidden, as delayed effect, in an effort to force the mind to digest this previously unclaimed kernel of experience."28

It is worth noting also, that intrusive memories are inextricable from the repetitive return of sounds. The memories of some traumatic experiences among survivors come with the intrusive recalls of the sounds or sometimes the feelings the experience generates. Winnie in the above passage seems to be haunted by the sound of her husbands' blood drops, a sensory piece of information that inhibits the process of memory formation and consequently leads to her fragmentation. This scene and the one related to Stevie's explosion fit perfectly into Bessel van der Kolk's studies on trauma and memory. ${ }^{29}$ According to van der Kolk, emotional arousal caused by overwhelming experiences hinders the normal functioning of the parts of the brain responsible for the integration and interpretation of received sensory information. When experiences are so shocking, the formation of what he names declarative memories $^{30}$ is held back, and consequently narrative memory becomes impossible. What the consciousness registers instead are images and sounds which, according to van der Kolk, are indelible in consciousness, and do not change over time.

This is best unravelled through Winnie's traumatic experiences where images of the past return against her will. Her problem is speaking them out loud. Winnie is reported in the narrative to be haunted by those images and sounds which are triggered by other shocking images. For instance, the memories of her childhood abuse and of her brother's sufferings are induced when she has witnessed Mr Verloc's body covered with blood. However, witnessing is incessantly resisted by the traumatized subject, according to Dori Laub who refers to the "collapse of witnessing" ${ }^{11}$ at the

${ }^{28}$ This definition is taken from Greg Forter's article: "Freud, Faulkner, Caruth: Trauma and the Politics of Literary Form," Narrative 15, no. 3 (2007), p. 259.

${ }^{29}$ The schematic representation of van der Kolk's model on the effect of emotional arousal on memory integration and formation is included in the Appendix. It is taken from Jennifer J. Freyd's book Betrayal Trauma: The Logic of Forgetting Childhood Abuse (Cambridge, MA: Harvard University Press, 1996), p. 100.

${ }^{30}$ Van der Kolk differentiates between "declarative memory" and "procedural memory." The former is a type of long-term memory that is responsible the ability to recall information, while the latter is related to the ability to remember how to do things. Procedural memory is etched in the mind in a natural way without the subject's awareness, whereas declarative memory involves the brain's cognitive interpretation and registration of information in order for the latter to be retrieved and remembered.

${ }^{31}$ Shoshana Felman, Dori Laub, Testimony: Crises of Witnessing in Literature, Psychoanalysis, and History (New York: Routledge, 1992). 
heart of the empirical event in itself. The collapse of witnessing entails Winnie's refusal of a cumbersome reality which she cannot dispose of.

\section{TIME, DEATH AND FRAGMENTATION}

The scene of Mr Verloc's death represents the watershed in Winnie's life. It does not only unfold the problems besetting her marriage, but it also forecloses the dissimulated violence underlying her ostensible calmness and "unfathomable reserve." Winnie finds herself consigned to a life of suffering and self-sacrifice, and her final backlash is indeed the consequence of a series of betrayals that she cannot endure. However, her vengeful reaction does not come unexpectedly, as she seems to be well prepared for it. In his attempts to quench the fires of Winnie's indignation, Mr Verloc tries to console her through the normalization of her brother's death, but his consolation does not placate Winnie; it rather whets her rage. Nevertheless, her encroaching fury comes with her calmness:

A loyal woman bound to that man by an unbroken contract, her right hand skimmed slightly the end of the table, and when she passed on towards the sofa, the carving knife had vanished without the slightest sound from the side of the dish. Mr Verloc heard the creaky plank in the floor, and was content. He waited. Mrs Verloc was coming. (TSA, p. 234)

The detailed description of Mr Verloc's death further heightens the tension and excitement induced by the act. Through the stretching of time to describe the instant, Conrad stresses the sinister aspect of the murder and transmits its gruesomeness to the reader.

Dwelling on the importance of time in relation to events in The Secret Agent, Paul Wake considers the non-representable nature of the instant of death. The impossibility to effectively put back events into a chronological linear order and construct a whole narrative along with the novel's structural anachrony reveal the existence of a breach in the time structures of the mind induced by witnessing death. Wake's studies on "narrative time" are premised on Paul Ricoeur's notion of "human time." "Time becomes human," Ricoeur holds, "to the extent that it is articulated through a narrative mode, and narrative attains full meaning when it becomes a condition of temporal existence." ${ }^{32}$ Human time manifests itself in a very effective way through the scene of Mr Veloc's murder. Wake argues that "the narrative fails to reiterate the instant of death as an instant." ${ }^{33}$ It rather stretches the time of describing the event, and thus confines Winnie in a past from which she cannot extricate herself since it becomes her present.

\footnotetext{
${ }^{32}$ Paul Ricoeur, Time and Narrative, trans. Kathleen McLaughlin and David Pallauer, 3 vols. (Chicago: Chicago University Press, 1984), qtd in Paul Wake, "The Time of Death: 'Passing Away' in The Secret Agent," The Conradian 32, no. 1 (2007), p. 16.

${ }^{33}$ Wake, "The Time of Death," p. 17.
} 
The scene of the murder is what brings the narrative tension to its extreme. It represents the climax of the story:

He saw partly on the ceiling a clenched hand holding a carving knife. It flicked up and down. Its movements were leisurely. They were leisurely enough for Mr. Verloc to recognize the limb and the weapon. They were leisurely enough for him to take in the full meaning of the portent, and to taste the flavor of death rising in his gorge. His wife had gone raving mad-- murdering mad. They were leisurely enough for the first paralyzing effect of this discovery to pass away before a resolute determination to come out victorious from the ghastly struggle with that armed lunatic. They were leisurely enough for Mr. Verloc to elaborate a plan of defense, involving a dash behind the table, and the felling of the woman to the ground with a heavy wooden chair. But they were not leisurely to allow Mr. Verloc the time to move either hand or foot. The knife was already planted in his breast. (TSA, p. 234)

However, it is not until the end of the scene that readers discover the difference between the time of representing the traumatic event and the time of its occurrence.

The disruption of chronology in the novel is also adumbrated through the chapters' arrangement which stands in contrast to the linear time of the story. This "double temporality" as Wake names it is linked to the novel's general theme of distorted chronology. "The theme of The Secret Agent," Robert Wooster Stallman argues "has to do with time, the destruction and confusion of time itself, and the confused chronology of narrated events by their disarrangement from time effects a structure which is at one with the theme." 34 The lack of a time structure of "wholeness" and linearity is indeed symptomatic of trauma. Taken into account the breach caused in the time structure of the mind upon witnessing the trauma, the Aristotelian tenet of emplotment, ${ }^{35}$ that is, the notion of a past, present and future is shacked since the narrative seems to be stuck in the time of the traumatic event. This idea is further substantiated by the pictorial representation of the clock during the scene of Mr Verloc's death. As it is mentioned in the narrative, the ticking sound of the clock seems to stop at the moment of his traumatic death, and hence leads to Winnie's insanity.

Time is blocked at the moment of the instant. Jacques Derrida describes the latter as "an aporia that cannot pass or come to pass." time of the trauma, resists narrative representation. Such an idea holds good in Winnie Verloc's claim that "clocks and watches always stop at the moment of murder for the undoing of the murderer" (TSA, p. 202). Winnie's inability to set forth a precise time for the instant of death implies the failure to include it in the narrative. Death occurs so soon and so unexpectedly that Winnie can neither register it nor retrieve it in a time sequence; thus, the instant of death, to use Herman's words, is "not encoded like the ordinary memories of adults in a verbal, linear narrative that is assimilated into an

${ }^{34}$ Robert Wooster Stallman, "Time and The Secret Agent." Texas Studies in Literature and Language 1, no. 1 (1959), pp. 101-122. Qtd in Wake, "The Time of Death," p. 17.

${ }^{35}$ Wake, "The Time of Death," p. 2. Emplotment infers the arrangement and rearrangement of events in a time sequence.

${ }^{36}$ Jacques Derrida, Aporias, trans. Thomas Dutoit (Stanford: Stanford University Press, 1993). Qtd in Wake, "The Time of Death," p. 16. 
ongoing life story." ${ }^{37}$ The shock creates a blank in the mind that disrupts any notion of time. For such events, Greg Forter uses the term "punctual traumas" which, he postulates, are less than "an ongoing set of processes" shaped by those living them. They are rather instant blows to the psyche that "overwhelm its functioning, disable its defenses, and absent it from direct contact with the brutalizing event itself." 38

The distortion of chronology and the gaps in time lead to narrative disjunctions and fragmentation. These gaps reflect the ones existing in thoughts and memories. Fragmentation, a major characteristic of modernist literature which laments disunity and seeks wholeness, can also express the psychological problem besetting Winnie's state of mind. Fragmentation, as Janina Fisher argues, is a form of dissociation when it is linked to trauma. "To fragment," she argues, "is to separate the part of personality that has gone through traumatic experiences from the one that has experienced other things in life." ${ }^{39}$ In The Secret Agent fragmentary images of death and torture prevail through the narrative, which further foments readers' daunting endeavours to find meaning for inscrutable experiences. Readers, like characters, seem to encounter "sudden holes in space and time," and this is what incessantly hampers the very process of understanding. In this respect, it is splitting hairs to reiterate Caruth's definition of trauma as "not locatable in the simple violent or original event in an individual's past, but in the way its unassimilated nature - the way in which it was precisely not known in the first instance-return to haunt the survivor later on." "40

Indeed, the unassimilated past reflects Winnie's splintered mind, for it returns as symbolic and incoherent. The sinister and intermittent revisitation of traumatic memories is pinned down in The Secret Agent via the unbidden images and sounds that interrupt Winnie's unruffled present. Such images, inducing a narrative mode of disarray and epistemological impasse, transmit the traumatic ruptures caused by grisly experiences since they re-enact, to use Caruth's term, or perform rather than formally represent what the victim intends to enunciate. Traumatic memories, Forter argues, "lie in part in their cognitive indigestibility." ${ }^{41}$ Winnie seems to be held hostage in Freud's concept of "repetition compulsion" as she cannot avoid the recursive incursions of her dismal past into her ostensibly calm present. Repetition compulsion also comes with the distortion of chronological sequence in Winnie's consciousness. With the re-enactment of moments of grief, the past and present become intermingled; the lack of chronological fluidity and epistemological veracity turn out to be the sole residue of her long journey of suffering.

Analysing the time-structure of The Secret Agent, Avrom Fleishman contends that in addition to chronological and historical time, another type of time usurps the novel. This is "lived and subjective time, the shape that time assumes in consciousness as

\footnotetext{
${ }^{37}$ Herman, Trauma and Recovery, p. 37.

${ }^{38}$ Forter, "Freud, Faulkner, Caruth," p. 259.

${ }^{39}$ Janina Fisher, Healing the Fragmented Selves of Trauma Survivors: Overcoming Internal SelfAlienation (New York: Routledge, 2017), p. 40.

${ }^{40}$ Caruth, ed., Trauma, p. 4, emphasis added.

${ }^{41}$ Forter, "Freud, Faulkner, Caruth," p. 260.
} 
events impress themselves upon it with varying emotional force." ${ }^{42}$ Time is represented as it is experienced and not as it is reworked or reshaped in narrative. The significance of time is exemplified through the omnipresence of clocks in the novel, which bears out the temporal blockage induced by the traumatic event. Winnie is aware of this impasse, but she seems to be careless about time:

Nothing moved in the parlor till Mrs Verloc raised her head slowly and looked at the clock with inquiring mistrust. She had become aware of a ticking sound in the room. It grew upon her ear while she remembered clearly that the clock on the wall was silent, had no audible tick. What did it mean by beginning to tick so loudly all of a sudden? Mrs Verloc cared nothing for time and the ticking went on. (TSA, pp. 264-265)

Conrad's deft and astute description of the clocks reveals the state of Winnie's consciousness. The latter seems to be engulfed by an array of temporal fissures that disrupt her assimilation of any notion of chronological linearity and harmony.

\section{“A SUBJECTIVITY WITHOUT A SUBJECT": WINNIE'S ATTEMPTS TO WORK THROUGH}

Mired in an inexorable haunting past that weighs down her sense of unity and coherence, Winnie seeks wholeness in her endeavours to reconstruct her lost subjectivity. The past in its "literal return against the will of the one it inhabits" causes an identity crisis among the victims of trauma." ${ }^{43}$ Accordingly, the devastating effect of traumatic experiences leaves Winnie's identity in an unremitting state of disintegration and loss. Winnie cannot come to terms with her traumatic past which incessantly bursts into her mind, leaving her in total dissonance with her subjectivity. Her successive encounters with death, violence and betrayal culminate in what Jonathan Boutler calls "a subjectivity without a subject," for the psychological imprint caused by traumatic experiences creates "some shift in the psyche, in the self, in the interiority of the subject, to the point where the subject finds himself to have become a trace of what he was, a cinder marking the passing of the disaster." ${ }^{44}$

Indeed, the upheavals in Winnie's subjectivity are the consequences of not only the repetition of her past traumas, but also of her daunting struggles for survival devoid of any feeling of guilt. As Jenny Edkins remarks: "It seems that it is not so much death that is traumatic as survival, or at least survival in the face of particularly brutal or incomprehensible deaths." ${ }^{45}$ The idea at stake seems to chime in with Caruth's

${ }^{42}$ Avrom Fleishman, "The Symbolic World of The Secret Agent," ELH 32, no. 2 (1965), p. 201.

${ }^{43}$ Caruth, ed., Trauma, p. 5.

${ }^{44}$ Jonathan Boutler, Melancholy and the Archive, Trauma, History and Memory in the Contemporary Novel (London-New York: Continuum, 1988), p. 9.

${ }^{45}$ Jenny Edkins, "Remembering Relationality: Trauma Time and Politics," in Memory, Trauma and World Politics. Reflections on the Relationship Between Past and Present, ed. Duncan Bell (Basingstoke: Palgrave Macmillan, 2006), p. 99. 
interpretation of Freud's concept of repetition compulsion. For Winnie, the latter consists not only in repeating moments of death, since they exist as blank memories in consciousness, but it refers also to the repetition of the very moment of "awakening" or survival. Caruth describes this moment of "awakening" as both unfathomable and indigestible in cognition. It is this unfathomable return that leaves Winnie's self entirely splintered and in a continual quest for meaning and wholeness. Accordingly, and in an act of paying penance in order to work through, Winnie elopes with Mr. Ossipon, her new lover, so as to dismiss a past marred by violence, agony and betrayal and start anew. Getting recursively immersed in horrendous experiences seems to take a toll on Winnie's sense of a whole self, for her endeavour to purge vestiges of the past from her present life proves to be a vain and ineffectual one. Winnie's relationship with Ossipon does not help her to live down her past traumas; instead it ushers her life into a new series of betrayals and sufferings. The new life she has chosen to lead and her failure to come to grips with past memories culminate in her suicide. Winnie cannot bear the nefarious action of Mr. Ossipon, and thus finds death the sole refuge from her past experiences.

Encapsulating this chapter, it is crucial to mention that The Secret Agent becomes a window through which readers can discern the gruesomeness of ordinary people's experiences of death, violence and the precariousness of social life. These social traumas, although they might be considered "mundanely" catastrophic by some trauma theorists, as they do not belong to trauma studies' original area of interest, are very important for broadening the scope of trauma studies, because they go beyond the restricted corpus of texts on the Holocaust.

Through the excavation of individual experiences, The Secret Agent becomes the site where the generic boundaries between fiction and non-fiction, individual and collective are undermined. Indeed, testimony plays a primary role in healing traumatic wounds, since divulging past memories and re-enacting them prove primordial in the therapeutic process. However, the inability to reveal appalling memories jeopardizes the victim's sense of unity and consequently his or hers conceptualization of subjectivity as a whole. Dori Laub, in her delineation of the importance of testimony, holds:

Survivors who do not tell their story become victims of distorted memory $[\ldots]$ the events become more and more distorted in their silent retention and pervasively invade and contaminate the survivors' daily life. The longer the story remains untold, the more distorted it becomes in the survivor's conception of it, so much so that the survivor doubts the reality of the actual events. ${ }^{46}$

This is revealed through Winnie's inability to articulate her dismal past in the narrative. Her taciturnity does not help her to overcome her agony. It rather enmeshes her in a state of confusion and apprehension since her sense of unity becomes entirely shuttered, which constitutes the turn of the screw in her life.

Furthermore, her silence and reluctance to speak explain her impending uncanny behaviour in the novel. This idea can also be gleaned from Freud's analysis of the

${ }^{46}$ Felman, Laub, Testimony, p. 68-69. 
notion of the "uncanny," 47 which he primarily relates to women. The uncanny for Freud is what arouses dread and horror; it is what leads Winnie's life to its end. Freud contends that the unheimlich $^{48}$ is inextricably linked to the return of the repressed. The latter, he explains, can be moored to something familiar that returns to haunt the present: "It may be that the uncanny (the unhomely) is something familiar (homely) that has been repressed and then reappears, and that everything uncanny satisfies this condition. I believe that it can be traced back every time to something that was once familiar and then repressed." 49 Trauma can also be linked to the concept of the uncanny, but only to some extent, since Freud's amalgamation of the repressed with the familiar seems to be controversial. To consider Winnie's immersion in violence, death and carnage as familiar seems to transcend the trauma genealogy Caruth commends because of its association with the unexpected and the shocking. However, the recursive exposure to scenes of death and betrayal renders the unfamiliar familiar; and thus leads to Winnie's uncanny behaviour. The latter is best expounded through the scene of Mr Verloc's murder. Her backlash comes too weirdly and unexpectedly since she has prepared herself to mourn her husband's death before the murder.

\section{WORKS CITED}

\section{Primary Sources:}

Conrad, Joseph. The Secret Agent. Cambridge: Cambridge University Press, 1984.

- The Collected Letters of Joseph Conrad. Vol. 8. Cambridge: Cambridge University Press, 2007.

\section{Secondary Sources:}

Boulter, Jonathan. Melancholy and the Archive, Trauma, History and Memory in the Contemporary Novel. London-New York: Continuum, 1988.

Caruth, Cathy, ed. Trauma: Explorations in Memory. Baltimore, MD: Johns Hopkins University Press, 1995.

_. Empirical Truths and Critical Fictions: Locke, Wordsworth, Kant, Freud. Baltimore, MD: Johns Hopkins University, 2009.

- Unclaimed Experience: Trauma, Narrative, and History. Baltimore, MD: Johns Hopkins University Press, 2016.

Edkins, Jenny. "Remembering Relationality: Trauma, Time and Politics." In Memory, Trauma and World Politics. Reflections on the Relationship Between Past and Present, edited by Duncan Bell. Basingstoke: Palgrave Macmillan, 2006.

${ }^{47}$ Sigmund Freud, "The Uncanny," in Fantastic Literature: A Critical Reader, ed. David Sander (Westport, CT: Praeger, 2004), pp. 74-101.

${ }^{48}$ This refers to the original German word for the "uncanny," which literally means "unhomely." The English term is not of course the exact equivalent of the German one.

${ }^{49}$ Freud, "The Uncanny," p. 75. 
Felman, Shoshana, and Dori Laub. Testimony: Crises of Witnessing in Literature, Psychoanalysis, and History. New York: Routledge, 1992.

Fisher, Janina. Healing the Fragmented Selves of Trauma Survivors: Overcoming Internal SelfAlienation. New York: Routledge, 2017.

Fleishman, Avrom. "The Symbolic World of The Secret Agent." ELH 32, no. 2, 1965, pp. 196-219.

Forter, Greg. "Freud, Faulkner, Caruth: Trauma and the Politics of Literary Form." Narrative 15, no. 3, 2007, pp. 259-85.

Freud, Sigmund. "Beyond the Pleasure Principle." Psychoanalysis and History 17, no. 2, 2015, pp. 151-204.

—. "The Uncanny." In Fantastic Literature: A Critical Reader, edited by David Sander, pp. 74-101. Westport, CT: Praeger, 2004.

Fryed, Jennifer J. Betrayal Trauma: The Logic of Forgetting Childhood Abuse. Cambridge, MA: Harvard University Press, 1998.

_ "Betrayal Trauma: Traumatic Amnesia as an Adaptive Response to Childhood Abuse." Ethics \& Behavior 4, no. 4, 1994, pp. 307-329.

Fridman, Lea Wernick. Words and Witness: Narrative and Aesthetic Strategies in the Representation of the Holocaust. New York: SUNY Press, 2012.

Giesbrecht, Timo, and Harald Merckelbach. "Betrayal Trauma Theory of Dissociative Experiences: Stroop and Directed Forgetting Findings.” The American Journal of Psychology 122, no. 3, (Fall 2009), pp. 337-348.

Giesbrech, Timo, et al. "Cognitive Processes in Dissociation: An Analysis of Core Theoretical Assumptions." Psychological Bulletin 134, no. 5 (2008), p. 617.

Harrington, Ellen Burton. "The Female Offender, the New Woman, and Winnie Verloc in The Secret Agent." The Conradian 32, no. 1, 2007, pp. 57-69.

Herman, Judith L. Trauma and Recovery: The Aftermath of Violence-From Domestic Abuse to Political Terror. New York: Basic Books, 2015.

Kaplan, Carola M. “'Sudden Holes in Space and Time': Trauma, Dissociation, and the Precariousness of Everyday Life." Psychoanalytic Inquiry 33, no. 5 (2013), pp. 467-478.

Kolk van der, Bessel A., and Alexander C. McFarlane, eds. Traumatic Stress: The Effects of Overwhelming Experience on Mind, Body, and Society. New York: Guilford Press, 1996.

Kolk van der, Bessel A., and Onno van der Hart, "The Intrusive Past: The Flexibility of Memory and the Engraving of Trauma." In Trauma: Exploration in Memory, edited by Cathy Caruth. Baltimore: Johns Hopkins University Press, 1995, p. 158-182.

LaCapra, Dominick. History, Literature, Critical Theory. Ithaca: Cornell University Press, 2013.

- Writing History, Writing Trauma. Baltimore, MD: JHU Press, 2014.

. History and Memory after Auschwitz. Ithaca: Cornell University Press, 1998.

Sherry, Norman. "The Greenwich Bomb Outrage and The Secret Agent." The Review of English Studies 18, no. 72 (1967), pp. 412-428.

Terr, Lenore C. "Childhood Traumas." Psychotraumatology (1995), pp. 301-320.

Wake, Paul. "The Time of Death: 'Passing Away' in The Secret Agent." The Conradian 32, no. 1, 2007, pp. 13-20.

Wolosky, Shira. Language Mysticism: The Negative Way of Language in Eliot, Beckett, and Celan. Stanford: Stanford University Press, 1995. 


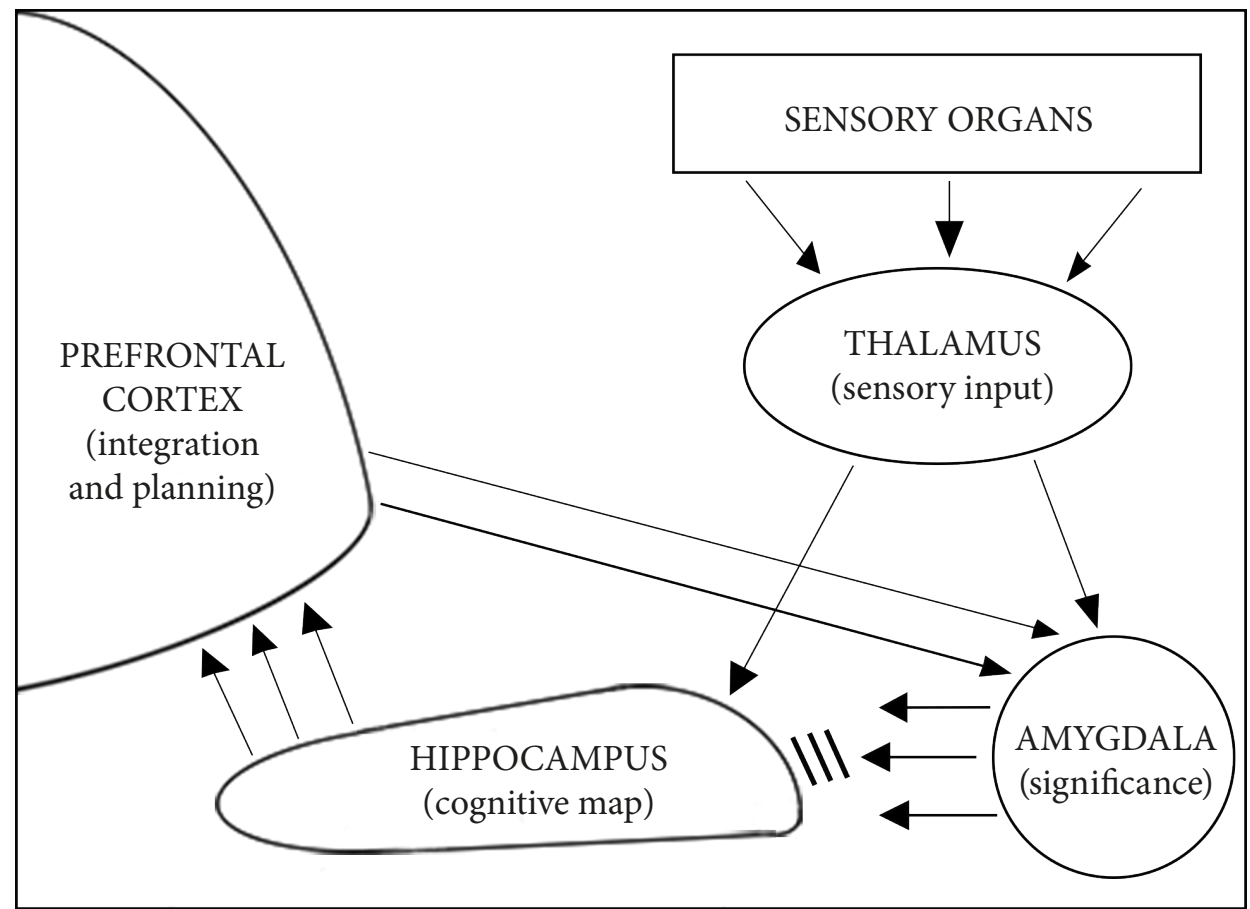

Figure 1. A schematic representation of van der Kolk's model of the effects of emotional arousal on declarative memory. The brain regions known as the thalamus, amygdale, and hippocampus are each involved in the integration and interpretation of incoming sensory information. According to this model, the thalamus projects sensory information to both the amygdale and hippocampus. Determination of emotional significance is mediated by the amygdala, and the creation of declarative memory is mediated by the hippocampus. Van der Kolk suggests that while moderate or high activation of the amygdale enhances memorability, thus ensuring good memory for mildly stressful experiences. Van der Kolk suggests that memories of traumatic experiences are then stored in sensorimotor modalities, such as somatic sensations and visual images, which he considers relatively indelible, as compared with the more reconstructive and thus changeable nature of episodic memory. ${ }^{50}$

${ }^{50}$ The schematic representation is taken from Jennifer J. Freyd's book Betrayal Trauma, p. 100. 
